\title{
1. It was the best of times; it was the worst of times
}

\author{
CHRIS AULICH
}

Charles Dickens began A Tale of Two Cities with the wonderfully evocative line that is the title of this chapter. It might well have described the fortunes of both major political parties in the period under review: the Commonwealth administration under Kevin Rudd from November 2007 until July 2010, when Rudd lost both the leadership of the Labor Party and the prime ministership.

In this period Rudd's approval ratings - extraordinarily high in the early days of his government - dropped to below 40 per cent by May 2010 (see Table 1.1), when one million voters turned away from Labor shortly after the government announced that it would not proceed with its emissions trading scheme (ETS) (Stuart 2010:267). From 27 per cent preferring Tony Abbott as prime minister in March 2010 to 41 per cent just four months later (Figure 7.3), the political landscape was volatile. A government with two prime ministers in three years and an opposition with three leaders during the same period, it will be recognised as one of the most turbulent periods in modern Australian political history. As Dickens might have said of the period: 'it was the age of foolishness, it was the epoch of belief...it was the spring of hope, it was the winter of despair' (Dickens 1859:3).

Having managed to respond very positively to the global financial crisis (GFC), Labor, in its spring of hope, saw a historic apology to the 'Stolen Generations', a full agenda for reforming intergovernmental relations and a succession of other policy initiatives covering a huge range of proposed government activity. Even after the demise of Kevin Rudd himself, this hope was again ignited by the appointment of Australia's first woman Prime Minister, Julia Gillard. Yet the period was also Labor's winter of despair, culminating in the failure of its firstterm government to be re-elected in its own right, with Gillard forced to accept the support of a number of Greens and independents to form her minority government. The Coalition, too, suffered its own winter with a turnover of leaders and disastrous poll results in the first two years of the Rudd ascendency. 
The Rudd Government

Table 1.1 Newspoll data, November 2007 - August 2010

\begin{tabular}{l|l|l|l|l} 
Date & \multicolumn{1}{l}{$\begin{array}{l}\text { Intended } \\
\text { primary } \\
\text { vote }\end{array}$} & \multicolumn{1}{l}{$\begin{array}{l}\text { Two party } \\
\text { preferred (ALP }\end{array}$} & $\begin{array}{l}\text { Approval } \\
\text { as prime } \\
\text { minister }\end{array}$ & \multicolumn{1}{l}{$\begin{array}{l}\text { Who would make the } \\
\text { better prime minister } \\
\text { (ALP - Coalition) }\end{array}$} \\
\hline Election 2007 & 43 & $53-47$ & \multicolumn{1}{l}{63 (Rudd) } & $47-44$ (Howard) \\
\hline 15-17 February 2008 & 46 & $57-43$ & 68 & $70-9$ (Nelson) \\
\hline 2-4 May 2008 & 47 & $57-43$ & 68 & $72-9$ \\
\hline 8-10 August 2008 & 47 & $57-43$ & 58 & $68-12$ \\
\hline 21-23 November 2008 & 42 & $55-45$ & 67 & $63-21$ (Turnbull) \\
\hline 6-8 February 2009 & 48 & $58-42$ & 63 & $62-20$ \\
\hline 15-17 May 2009 & 46 & $56-44$ & 58 & $58-24$ \\
\hline 21-23 August 2009 & 44 & $55-45$ & 61 & $66-19$ \\
\hline 13-15 November 2009 & 43 & $56-44$ & 56 & $63-22$ \\
\hline 12-14 February 2009 & 39 & $53-47$ & 50 & $55-27$ (Abbott) \\
\hline 14-16 May 2010 & 37 & $50-50$ & 39 & $49-33$ \\
\hline 6-8 August 2010 & 38 & $51-49$ & 43 (Gillard) & $49-34$ \\
\hline
\end{tabular}

Source: <www.newspoll.com.au/cgi-bin/polling/display_poll_data.pl>

The Coalition's period of hope began, however, with the steady emergence of Tony Abbott as a genuine alternative prime minister - coming tantalisingly close to victory in 2010. ${ }^{1}$ Nevertheless, the current period threatens to be Abbott's winter as he learns to deal with a substantively new role for an opposition leader facing a minority government, and he confronts potential challenges from the ever-present Malcolm Turnbull should he falter in grasping the complexities of this new role. While the period after the election presented a thrilling climax to the period under review, we leave its analysis to the authors of the next book in this series. In this volume, we concentrate primarily on the Rudd prime ministership.

We left the ninth book in the Commonwealth Administration series ${ }^{2}$ with a quote from Mungo MacCallum to illustrate the momentum and the level of excitement that had accompanied the incoming Rudd government in November 2007 (Aulich and Wettenhall 2008:1). This excitement was to reach stratospheric heights with the apology to the Stolen Generations and the Australia 2020 Summit. Two years later, however, Rudd's slide was as dramatic as his rise and was accompanied by a series of policy failures and a succession of problems that hampered Labor implementing those policies, which had promised the Australian people a period of significant and potentially visionary change.

\footnotetext{
1 At no stage, however, was Abbott able to match either Rudd or Gillard in the polls for preferred prime minister.

2 For a full list of the volumes in this series, see Appendix 1.1.
} 
This book traces that journey through the same approach taken in the past few books in this series. The book is divided into four parts: the first provides an overview of the period, beginning with John Wanna's chapter outlining the Rudd program and identifying his many agendas. After discussing the bases of the Rudd election program, Wanna describes the agendas initiated by Labor and the crafting by Rudd of a program based on the 'great battle of ideas'. The list is exhaustive, as Wanna highlights the many issues that emerged as 'firstorder' ones. Wanna then explains the demise of Rudd, providing an argument that is developed in almost all of the chapters to follow. His conclusion that Rudd will 'undoubtedly go down as a prime minister who promised much, but who actually achieved relatively little' becomes a dominant theme throughout the volume. It should be noted, however, that the early Rudd approach was characterised by his willingness to openly identify and debate his agenda and discuss his political values in a very public way. This provided a stark contrast with his predecessor, John Howard, who avoided engaging public debate on some of his more radical proposals, especially those such as privatisation, which had helped to reshape the Australian state by giving strong preference to individual over collective interests. This author has described this avoidance as constituting a 'legitimacy deficit' (Aulich 2010).

The second part of this volume focuses on changes to the institutions of government. It contains five chapters - all written by researchers who have made significant contributions to the series at previous times. John Halligan discusses the changes to the public sector in general and the Australian Public Service (APS) in particular. He identifies in the period tendencies towards steering strategically and moves towards centralising the APS, referring to this as a move towards 'one APS'. Halligan concludes that there was a massive reform agenda for modernising the Public Service and for building its capacity, especially in strengthening its role in policy making. He also identifies, however, much unfinished business in this reform agenda, which he generously labels as 'underdeveloped'. Significantly, neither of the two main parties indicated during the election campaign any willingness to progress the 'blueprint' for a new public service that had been initiated by Terry Moran, Secretary of the Department of the Prime Minister and Cabinet, so it remains to be seen whether or not this initiative will be a key agenda for the new Gillard government.

To bookend Halligan's discussion about the inner public sector, Roger Wettenhall again chronicles the state of the outer public sector, comprising the nondepartmental public bodies (NDPBs). As in previous volumes in this series, here Wettenhall appends details of those NDPBs that have been established, changed or abolished in the period under review. In continuing this important research over a long period, Wettenhall's conclusion that 'the Commonwealth's NDPB sector is currently not working badly, though there are black spots' can be 
taken as a highly credible evaluation of the current state of this sector. Similarly, his conclusion that those centralising forces - also identified by Halligan - need to be carefully examined before significant decisions affecting the NDPB sector are implemented warrants serious attention by governments.

Former Clerk of the Senate, Harry Evans, discusses the issues faced by the Rudd government in managing a senate in which Labor was in a minority. Evans provides a succinct and plausible argument that lack of control of the Senate could be good for governments and that the Rudd government suffered little from senate obstructionism in comparison with its predecessor Howard governments. He makes the point that securing a majority senate could have contributed to the undoing of the last Howard government, as highly partisan measures, such as Howard's workplace relations legislation, can ultimately be harmful to their authors when there is little need to negotiate with others. If Evans's views can be translated to the incoming minority Gillard government then we could look forward to a period of 'good', if less stable, government.

Geoff Anderson and Andrew Parkin continue the analysis of intergovernmental relations that they began in the previous volume. They document the extraordinary level of activity initiated through the Council of Australian Governments (COAG) and the many initiatives that flowed from what was apparently a genuine attempt by the Rudd government to develop intergovernmental relations as one of its defining initiatives. They argue that much of the work is, however, unfinished or has run aground. Harsher critics have labelled the incursion of the Commonwealth into areas of state responsibility as one where 'the constraints of multi-tiered government placed Kevin Rudd's lofty goals out of reach' because they 'depended on the cooperation of other governments and organisations beyond his control' (Mulgan 2010:4-5). Indeed, Mulgan goes on to claim that Rudd's 'impossible ambitions...killed his prime ministership' because they exposed his ineffective leadership.

In previous volumes in the series, little attention has been paid to the opposition; typically, they appear as 'extras' to the main act. In this volume, we break with that tradition, and Gwynneth Singleton traces the fortunes of the opposition throughout the Rudd period using the polls as her signposts. She discusses the turbulence in the opposition parties that led to the election of three leaders in as many years, culminating with Tony Abbott. Singleton argues that the contrast between Abbott and his predecessors brings into focus the contested view of the primary role of Her Majesty's Opposition. Both Turnbull and Brendan Nelson were less adversarial and indicated that, at times, bipartisan approaches might be needed to develop policy in the national interest; Abbott, in contrast, vowed to lead an opposition that would exist primarily to oppose rather than to support the government (Daley 2010). Singleton also discusses the roles played by the opposition in contributing to policy development-perhaps a most prescient 
discussion in the light of the election of a minority Gillard government that will need to work more in coalition with minority parties in order to implement its agendas.

The third part of the book deals with the key policy issues faced by the Rudd government. Given the wide front on which the Rudd government worked, selecting key policy areas to be canvassed in this book has been challenging. We have favoured those that were controversial or represented significant change from the past or, as in the case of foreign policy, were intrinsically so significant that we felt they should be documented, even if there was a large degree of bipartisanship involved. We have selected education, the economy, Indigenous affairs, the environment and foreign policy as the focus of this policy sectionperhaps an arguable choice but one we think best captures the mood for change that characterised the Rudd period.

The section is prefaced with a chapter on policy making itself: policy experts David Marsh, Chris Lewis and Paul Fawcett combine to analyse the ways in which Rudd made and implemented citizen-centred policy making - an initiative that had been included in Labor's 2007 policy platform. The authors draw from two politically salient cases - the 2020 Summit and the Community Cabinet initiative - to argue that the Rudd government used the discourse of increased participation in the policymaking process largely as a means of legitimising or promoting decisions that had already been taken. When considered with views discussed elsewhere in the volume that policy decisions under Rudd became focused on the cabal or 'kitchen cabinet' of four senior ministers, the conclusions reached by these authors represent a strongly negative evaluation of Labor's efforts to enhance network governance and community participation in policy making.

Rudd's government sought to implement a 'revolution in the quantity of our investment in human capital and in the quality of outcomes that the education system delivers' (Rudd and Smith 2007). On stepping down from the prime ministership, Rudd spoke of the achievements of his government and listed education as one of his successes. In the chapter on the 'education revolution', Carole Kayrooz and Stephen Parker map the many programs that were part of the 'revolution' in schools and the vocational education and training (VET) and higher education sectors. They conclude that the impressive list of activities undertaken by the Rudd government certainly represented a significant investment. They warn, however, that 'a massive spend on infrastructure does not make a revolution', and argue that Rudd's education program, while well intentioned, did not effectively address longstanding educational issues.

Anne Garnett and Phil Lewis continue the story of the economy and industrial relations under Rudd, and they give the Rudd government few plaudits for 
its economic achievements. In particular, they criticise policies that generated waste, fostered incompetent policy oversight and failed to invest in productive infrastructure, favouring, instead, policies of short-term spending stimulus. They do acknowledge that the Rudd government was quick to respond to the GFC and that this was one factor in Australia's success in comparison with other countries; they argue that the stimulus package did have some short-run effect in preventing unemployment rising more than it would otherwise have, but argue that much of the spending was needlessly wasteful and has damaged longterm growth.

Garnett and Lewis also acknowledge that others might provide more generous interpretations of Labor's economic policies; indeed, Nobel laureate Joseph Stiglitz was reported as saying that 'Labor did a fantastic job of saving Australia from the global economic crisis' (Sydney Morning Herald 2010) — a view echoed by former Liberal Prime Minister Malcolm Fraser (ABC 2010a). What this does is to underline the alternative views of the management of the economy that were presented to the Australian people before the 2010 election.

Andrew Macintosh, Deb Wilkinson and Richard Denniss combine to tell the story of climate change, the issue that contributed significantly to the fall of the Prime Minister and two leaders of the opposition. They acknowledge the high priority given to climate change by Prime Minister Rudd in referring to it as the 'greatest moral, economic and environmental challenge of our generation' (Rudd 2007), and note that the issue was to be one of the defining policies of the new era, whereby Rudd would demonstrate that the Labor Party was the champion of progressive reform. The chapter then describes how that policy was steadily diluted following substantial pressure from the opposition and from the Greens, until finally, the initiative was abandoned as Labor was unable to secure its legislation through both houses of Parliament.

Will Sanders and Janet Hunt write about one of the most significant early achievements of the Rudd government in finally responding to claims from Indigenous Australians to say 'sorry' for past policies that had so badly impacted on them. They argue, however, that the promise of a new focus on Indigenous matters slowly petered out, as the paradigm in which the policy was embedded remained unchanged, despite the rhetoric of partnership espoused by the Rudd government. In their chapter, Sanders and Hunt claim that a generational revolution is needed before appropriate policies can be developed to meet the present situation; they argue strongly for a new way of thinking about Indigenous affairs with policies that best manage the tensions between equality, choice and guardianship.

It is rare in a federal election campaign that foreign policy is so little mentioned. After assuming government, Rudd certainly developed a more nuanced and 
multilateral approach to foreign policy than that preferred by his predecessor. Andrew Carr and Chris Roberts assert that on major policies, however, such as the war in Afghanistan and on asylum-seekers, there was little to distinguish the main parties. Certainly, Rudd strode the international stage in relation to managing the GFC and to the Copenhagen climate change summit but, Carr and Roberts argue, in terms of concrete foreign policy change, aside from withdrawing combat troops from Iraq, Rudd over promised and under delivered.

The fourth and final part of the book focuses on Kevin Rudd and his leadership. Mark Evans argues that the Rudd 'debacle' clearly demonstrates that sustainable prime ministerial power rests on the incumbent's recognition that their powerbase is determined by a broad set of resource dependencies encompassing the core executive territory, media relations, the citizenry and the Prime Minister's party itself. He suggests that as soon as Rudd lost sight of the importance of his resource dependencies he started to lose his grip on power. Evans contrasts Rudd's failure to hold on to his leadership with the earlier successes of Bob Hawke and John Howard, and in so doing provides a template for serious consideration of successful leadership by future political leaders.

\section{A series of failures}

This volume features contributions from a number of academics - some regarding the Rudd government more warmly; most, however, less enthusiastic about its achievements. In reviewing all of the chapters included in this volume, it is clear that Rudd promised much but, due to a number of circumstances, his government disappointed overall. As Gillard so succinctly put it on assuming the prime ministership, 'it was a good government that in some areas had lost its way' (Kenny 2010). This raises the question about where Labor had lost it way, and it seems that it raises a series of themes, all of which point to failure of some sort or other.

A first failure was to promise so much and deliver so little in terms of hard outcomes. The Rudd government was afflicted by 'initiativitis' (Stoker 2000:6), or, as John Wanna describes in the next chapter, it became 'a government of announcements'. Governments gain kudos from announcing initiatives, but gain few from the implementation and evaluation of those same initiatives. Ministers queue to make announcements about new programs but are too rarely sighted when details about implementation are required. As noted by John Wanna in Chapter 2 and Mark Evans in Chapter 14, the Rudd agenda was breathtaking in its scope, and also in its hyperbole: 'the big education reforms', an ETS that would respond to the 'greatest moral challenge of our time', advancing causes 
such as provisions for the homeless and closing the gap between Indigenous and other Australians, assuming control of hospitals unless the states were able to demonstrably improve their management of those facilities, making schools more open and accountable. The list of projects labelled as high priority surely eroded the significance of each; opposition senate leader, Nick Minchin, noted the number of times Rudd had talked about different policy areas as his 'No. 1 priority' (van Onselen 2010). A second list - of implementation failures - could also be factored into any judgment of government achievements: the 'pink batts' fiasco, the buildings and computers for schools programs, Indigenous housing, and fuel and grocery watch schemes, among others, displayed failures in implementation with the Rudd government required to defend its performance in these key policy areas. This volume records a number of other programs that, while not the public disasters mentioned above, either petered out or lost momentum. Programs such as advancing reconciliation beyond 'sorry', healthcare reforms and a number of the COAG initiatives remain incomplete though at times they were touted as primary targets for reform. As Richard Mulgan (2010) notes, Rudd had a 'penchant for ambitious commitments that proved impossible to meet' - a theme that resonates through most chapters in this volume.

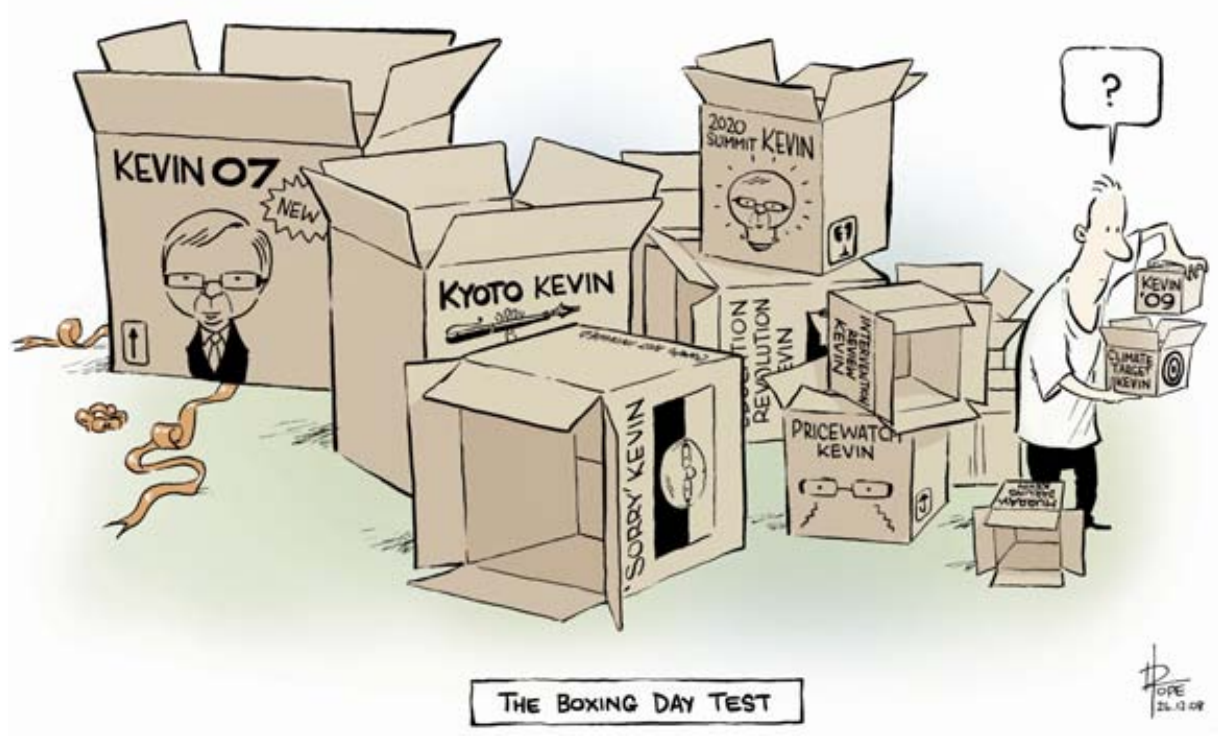

Source: David Pope, The Canberra Times, 26 December 2008 
A second failure was in communicating those successes that had been made. In particular, the quick response to the GFC - despite the waste that concerned Garnett and Lewis (see Chapter 10) - gave Australia a stronger chance to survive the GFC in sound economic condition. While there might have been some wasted opportunities in not investing sufficiently in long-term productive infrastructure development, it was not until the third week of the election campaign that Labor was prepared to cite its record of economic management as evidence that the electorate could trust it to manage the economy better than the opposition parties. Labor also did not trumpet other achievements such as those initially secured in health, reconciliation and in some COAG activities. Its 2010 election manifesto was more a statement about the future, as if somehow the past three years had yielded little for which Labor could claim credit.

A third failure lay in the role of ideas. It was clear that during the 2010 election campaign Gillard did not have or was not allowed to canvass new and radical ideas for her next government. Most commentators have lamented that the campaign was one that contained few serious policy debates, with both of the main parties relying on safety-first campaigns that revealed few policies that signalled significant change (or challenge!). ${ }^{3}$ While Abbott's campaign was to repeat a mantra of opposition (to wasteful spending, debt, new taxes, and to asylum-seekers), Labor was unable to capture the spirit of change promised with a new prime minister aiming to get Labor 'back on track'. This was never better represented than in the 'debate' about border protection. We witnessed an unedifying discussion on immigration between the Prime Minister and the Leader of the Opposition-ironically, both immigrants - trying to outdo each other with their plans to curb the current levels of immigration! And all in the name of winning the votes of a few xenophobic Australians who happen to live in marginal electorates.

The final failure was in leadership. As Peter Hartcher (2010) argues, candidates for leader 'should have the ability to inspire and elevate society with a bold, engaging vision' rather than simply reflecting the current views of the community. For a party of change such as Labor, its loyal adherents can reasonably expect that it will promote to the broader community a vision for the future, likely based on traditionally held social democratic values. Clearly, the Rudd government did begin with a vision of an Australia that was moving away from the Howard-Thatcher notions of individualism towards a view of society in which collective activity was again to be recognised, encouraged and applauded. Rudd's earlier musings about the death of neo-liberalism fostered hope by many that Labor would lead Australia towards a new age of

3 Mungo MacCallum (2010) described the campaign thus: 'Never had the prime ministership of Australia been contested by such a pair of abject, craven, weak-kneed, whey-faced, chicken-hearted, lily-livered, jellybellied milksops.' 
compassionate and collective government activity. It became clear, however, that as Labor jettisoned much of its vision-certainly with respect to issues such as the ETS and the management of immigration - disillusion began to set in among the electorate. As Jack Waterford (2010) asked presciently in May 2010 as Rudd's popularity began to crumble, 'has Labor any abiding belief?' This theme began to resonate with the electorate and it was hardly surprising that so many of Labor's 'true believers' deserted the party for alternatives such as the Greens, cast informal votes or failed to attend the polling booths at all. ${ }^{4}$ This represented a failure of Rudd's leadership to bring his constituency with him. As Mark Evans suggests in Chapter 14, Rudd forgot that he was dependent on the resources and support of his party, his cabinet colleagues, the Public Service and the Australian electorate.

In the future, when we evaluate the Rudd government from the safer distance of time, a verdict that focuses on failure might appear to be too tough. Perhaps when Australia inevitably moves towards adopting some mechanisms to contain carbon emissions, or shifts to new-generational policies for Indigenous affairs, or finally recasts intergovernmental relations as a genuinely collaborative activity, some commentators will note that the seeds of these policies were sown during the Rudd period. Perhaps these commentators will wonder why these and other initiatives were not brought to fruition at the time; this will probably generate further discussion about broad issues such as the importance of well-planned policy implementation or the role of leadership in engaging the citizenry. More cautious governments might reflect on the dangers of overreaching by promising more than is reasonable or possible to deliver; or that openness in government in turn generates further demands for even more openness. It was clear that, with respect to transparency and accountability, Rudd was committed to the importance of performance management, introducing mechanisms such as midterm reports, annual reports on 'closing the gap' and measuring the performance of schools and hospitals. When his constituency turned its attention to the Rudd government's performance, however, it found that Labor was still a 'work in progress' with few tangible indicators of successful implementation.

Many have noted the speed of Rudd's departure; this probably related most to his style of leadership. As Mark Evans has noted in Chapter 14, he preferred to work with a tightly held group of confidants and, in so doing, he alienated many of his cabinet and caucus colleagues. Perhaps when the challenge came to his leadership, many might have felt that he deserved support, given the difficulties that his government had surmounted, especially in relation to the GFC. When he sought this support, however, there were few willing to take

4 'The 2010 election appears to have had the highest number of informal votes in at least the last six federal elections' (ABC 2010b); and 'more voters refused to vote than at any election since 1925, the first election at which voting was made compulsory' (The Age 2010). 
up his case for him. None will forget his long and emotional final speech or the forlorn figure he cut when showing up to Question Time the day after he had lost his prime ministership. For Rudd, this must have been his 'worst of times'.

Chris Aulich is a Professor at the ANZSOG Institute for Governance, University of Canberra.

\section{References}

Aulich, C. 2010. 'Privatisation in service delivery: lessons from Australia', in T. Moon Joong (ed.), The Service Sector Advancement: Issues and implications for the Korean economy, Korean Development Institute, Seoul.

Aulich, C. and Wettenhall, R. (eds) 2008. Howard's Fourth Government: Australian Commonwealth Administration 2004-2007, UNSW Press, Sydney.

Australian Broadcasting Corporation (ABC) 2010a. Q \& A, ABC TV, 30 August, $<$ www.abc.net.au/tv/qanda $>$

Australian Broadcasting Corporation (ABC) 2010b. 'Figures show 5pc of votes were informal', $A B C$ News, 22 August, <www.abc.net.au/news/ stories/2010/08/22/2989878.htm>

Daley, P. 2010. 'Abbott takes aim at a PM all at sea', The Age, 3 January, $<$ www.theage.com.au/opinion/politics/abbott-takes-aim-at-a-pm-all-at-sea20100102-lmgg.html>

Dickens, C. 2005 [1859]. A Tale of Two Cities, The Folio Society, London.

Hartcher, P. 2010. 'Should we expect more from our leaders?', Sydney Morning Herald, 28 July, p. 2.

Kenny, M. 2010. 'Julia Gillard replaces Kevin Rudd as Prime Minister of Australia', AdelaideNow, 24 June, <www.adelaidenow.com.au/news/national/ruddfaces-party-challenge-number-crunch/story-e6frea8c-1225883388264>

MacCallum, M. 2010. 'The wimp and the wuss', Crikey, 26 July, <http:www. crikey.com.au>

Mulgan, R. 2010. 'Impossible ambitions that killed a prime ministership', The Public Sector Informant, July, pp. 4-5. 
Rudd, K. 2007. Address to the UN Bali Conference on Climate Change, Bali, 12 December, <www.australianpolitics.com/2007/12/12/rudd-address-to-baliclimate-change-conference.html>

Rudd, K. and Smith, S. 2007. The Australian Economy Needs an Education Revolution, Australian Labor Party, Barton, ACT.

Stoker, G. 2000. New Labour and local government modernisation, Paper presented to Local Government at the Millennium Conference, 21 February.

Stuart, N. 2010. Rudd's Way: November 2007-June 2010, Scribe, Melbourne.

Sydney Morning Herald 2010. 'Labor saved Australia: Nobel laureate Stiglitz', Sydney Morning Herald, 6 August, <www.smh.com.au/business/labor-savedaustralia-nobel-laureate-stiglitz-20100806-11lkq.html>

The Age 2010. 'The great turnoff', The Age, 21 September.

van Onselen, P. 2010. 'Seeing right through Rudd's changing top priorities, The Australian, 24 February.

Waterford, J. 2010. 'Has Labor any abiding belief?', The Canberra Times, 5 May.

\section{Appendix 1.1 Australian Commonwealth Administration series}

Australian Commonwealth Administration 1983: Essays in review, Alexander Kouzmin, J. R. Nethercote and Roger Wettenhall (eds) 1984, School of Administrative Studies, Canberra College of Advanced Education in association with ACT Division, Royal Australian Institute of Public Administration, Canberra.

Australian Commonwealth Administration 1984: Essays in review, J. R. Nethercote, Alexander Kouzmin and Roger Wettenhall (eds) 1986, School of Administrative Studies, Canberra College of Advanced Education in association with ACT Division, Royal Australian Institute of Public Administration, Canberra.

Hawke's Second Government: Australian Commonwealth Administration 19841987, Roger Wettenhall and J. R. Nethercote (eds) 1988, School of Management, Canberra College of Advanced Education, and ACT Division, Royal Australian Institute of Public Administration, Canberra. 
Hawke's Third Government: Australian Commonwealth Administration 19871990, John Halligan and Roger Wettenhall (eds) 1992, School of Management, Canberra College of Advanced Education, and ACT Division, Royal Australian Institute of Public Administration, Canberra.

From Hawke to Keating: Australian Commonwealth Administration 1990-1993, Jenny Stewart (ed.) 1995, Centre for Research in Public Sector Management, University of Canberra, and Royal Institute of Public Administration Australia, Canberra.

The Second Keating Government: Australian Commonwealth Administration 1993-1996, Gwynneth Singleton (ed.) 1997, Centre for Research in Public Sector Management, University of Canberra, and Royal Institute of Public Administration Australia, Canberra.

The Howard Government: Australian Commonwealth Administration 1996-1998, Gwynneth Singleton (ed.) 2000, UNSW Press, Sydney.

Howard's Second and Third Governments: Australian Commonwealth Administration 1998-2004, Chris Aulich and Roger Wettenhall (eds) 2005, UNSW Press, Sydney.

Howard's Fourth Government: Australian Commonwealth Administration 20042007, Chris Aulich and Roger Wettenhall (eds) 2008, UNSW Press, Sydney. 